\title{
Greenhouse gas sources and mitigation strategies from a geosciences perspective
}

\author{
Daniel J. Soeder ${ }^{1,2}{ }^{\oplus *}$ \\ ${ }^{1}$ Soeder Geoscience LLC, West Virginia 26444, USA \\ ${ }^{2}$ Department of Geology and Geography, West Virginia University, West Virginia 26506, USA
}

Keywords:

Fossil fuels

climate change

greenhouse gas

carbon capture

carbon storage

\section{Cited as:}

Soeder, D. J. Greenhouse gas sources and mitigation strategies from a geosciences perspective. Advances in Geo-Energy Research, 2021, 5(3): 274-285, doi: 10.46690/ager.2021.03.04

\begin{abstract}
:
Certain gases that are capable of trapping heat in the Earth's atmosphere are known as "greenhouse gas" and are important for helping to regulate temperature. Major greenhouse gases include carbon dioxide, methane, water vapor, chlorofluorocarbons, and nitrous oxide. Burning fossil fuels produces carbon dioxide as a combustion product and atmospheric concentrations have increased dramatically over the past two centuries. The heat trapped by this additional greenhouse gas is changing climates, melting ice sheets and glaciers in polar regions, raising sea levels, and affecting ocean currents. Climate change can be mitigated by preventing the emission of additional fossil fuel combustion products to the atmosphere and reducing existing greenhouse gas levels back to pre-industrial revolution concentrations. This requires switching energy production to sustainable, nonfossil sources and applying carbon capture, use, and storage technology on the fossil fuel combustion that remains. The implementation of direct air capture technology to reduce existing carbon dioxide levels in the atmosphere can further remediate climate impacts. Captured carbon dioxide can be stored in plant tissues, soils, deep underground in geological repositories, or as solid materials like concrete or carbonates to keep it from reentering the atmosphere. Although non-carbon energy sources have recently become more cost-competitive with fossil energy, technological advancements and government policies are still needed to overcome the inherent economic advantages of fossil fuels. A global strategy must be developed to convince people that the higher cost of clean, sustainable energy is a price worth paying to replace fossil fuels and prevent a major environmental calamity.
\end{abstract}

\section{Introduction}

Multiple measurements and data sets show unequivocally that levels of carbon dioxide $\left(\mathrm{CO}_{2}\right)$ have been increasing in the Earth's atmosphere for the past several centuries, with the rate becoming steeper in recent decades. Carbon dioxide is known as a "greenhouse gas" (GHG) because of its ability to trap heat in the atmosphere. Other GHGs include methane $\left(\mathrm{CH}_{4}\right)$, a waste product of anaerobic bacteria and the main component of natural gas, nitrous oxide, a product of both plant decay and high-temperature combustion, and chlorofluorocarbons, used as refrigerants in the past but banned by the Montreal Protocol in 1996 for damaging the Earth's ozone layer. Even water vapor has heat-trapping properties. The trends toward greater concentrations of some of these gases in the atmosphere and their potential effects on climate have alarmed nearly all scientists around the world.

The potential for certain gases like $\mathrm{CO}_{2}$ to trap heat in the atmosphere has been known since the early $19^{\text {th }}$ Century, but the modern recognition of potential problems came from computer simulations that incorporated basic elements of the Earth's climate into numerical models and found definitive links between changes in water vapor and $\mathrm{CO}_{2}$ levels and effects on global temperatures (Manabe and Wetherald, 1967).

An atmospheric carbon dioxide observatory on the flank of the Mauna Loa volcano in Hawaii was established in 1957 by the U. S. National Oceanic and Atmospheric Administration (NOAA) and the Scripps Institute of Oceanography. Nearly two decades of data showed an unexpected and rather alarming trend of rising $\mathrm{CO}_{2}$ levels in the atmosphere (Keeling et al., 


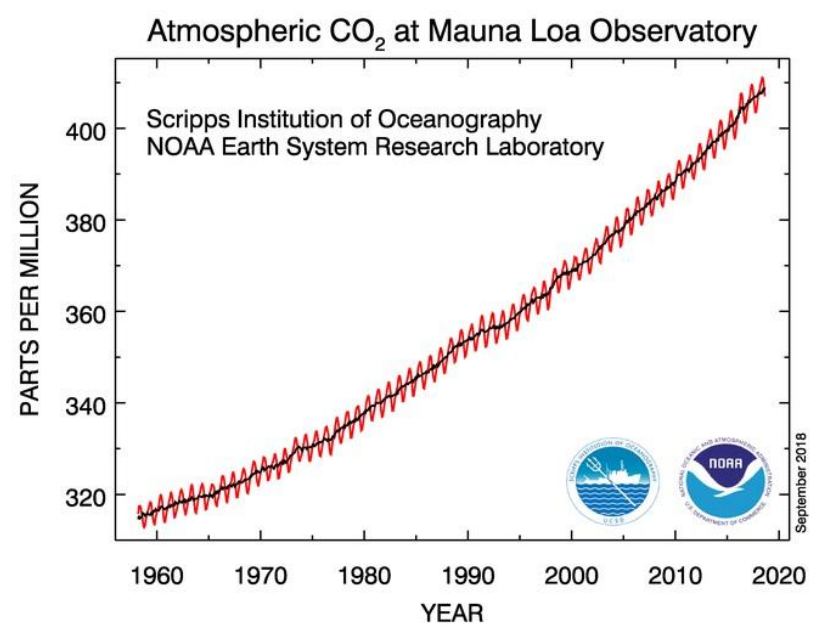

Fig. 1. The Keeling Curve of carbon dioxide levels in the atmosphere measured since 1957 at Mauna Loa in Hawaii. The sawtooth pattern represents seasonal changes in $\mathrm{CO}_{2}$ as northern hemisphere plants bloom in spring and go dormant in fall. The solid line up the center is the annual average trend. Source: U. S. NOAA public domain.

1976). The iconic image shown in Fig. 1 is known as the "Keeling Curve" after their 1976 paper. Atmospheric $\mathrm{CO}_{2}$ concentration has increased by nearly 100 parts per million (ppm) or around 30 percent over the past 60 years. In response to this trend of rising $\mathrm{CO}_{2}$ levels, the United Nations established the Intergovernmental Panel on Climate Change (IPCC) in 1988 under the auspices of the United Nations Environment Program (UN Environment) and the World Meteorological Organization. The IPCC and its specialist subcommittees synthesize climate data from international research efforts and release periodic reports, which are carefully reviewed to be both objective and transparent (https://www.ipcc.ch/). The goal is to provide technical input for international policy negotiations to address climate change.

\section{GHG}

In 1824, French physicist Joseph Fourier (probably better known these days for the Fourier infinite mathematical series that bears his name) identified the heat-trapping properties of carbon dioxide while investigating radiative heat transfer in the atmosphere. Fourier found that $\mathrm{CO}_{2}$ was transparent to shorter wavelengths of infrared radiation (IR), but it blocks and absorbs longer IR wavelengths. Eunice Foote, a U. S. physicist from Seneca Falls, New York ran experiments in 1856 where she exposed different gases in glass cylinders to sunlight and discovered that the cylinder with $\mathrm{CO}_{2}$ trapped more heat and stayed hot longer (McNeill, 2016). The investigation was expanded in 1859 by John Tyndall in Ireland with additional gases. The infrared absorption bands for $\mathrm{CO}_{2}$ were precisely measured by Martin and Barker (1932) centered on wavelengths of 4.3 micrometers $(\mu \mathrm{m})$ and $15 \mu \mathrm{m}$. Recently, researchers were able to independently confirm with observational evidence and sophisticated data processing techniques that from 2003 through 2018 the radiation imbalance between the bottom and the top of the atmosphere has grown wider, primarily due to rising concentrations of GHG and the reduction of reflective aerosols (Kramer et al., 2021). Since the amount of incoming solar radiation can be assumed to be essentially constant over longer time scales, these findings imply that if less heat is leaving the Earth's atmosphere, more is being trapped. The outputs of many sophisticated climate models clearly indicate that such excess heat will result in climate change.

\section{Sources of GHG}

Where do these GHGs originate? Some people who argue against human-induced climate change claim that the GHG can be attributed to natural sources, such as volcanic eruptions, swamp gas, rotting vegetation, and even cattle flatulence. The sawtooth pattern on the Keeling Curve in Fig. 1 shows the annual cycle of the $\mathrm{CO}_{2}$ content in the atmosphere as northern hemisphere plants bloom in the spring and take up the gas. These plants then either die back or go dormant in the autumn and release the $\mathrm{CO}_{2}$ back into the atmosphere. The small scale of these natural swings in $\mathrm{CO}_{2}$ concentration compared to the upward trend and magnitude of the multi-year average clearly indicates that vegetation cannot be responsible for the decadeslong, steady increase.

Although volcanic eruptions may emit copious quantities of $\mathrm{CO}_{2}$ into the atmosphere, there have not been any large eruptions sustained continuously (and actually increasing) since 1957 to account for the Keeling Curve. Episodic megaeruptions large enough to affect the measurement would certainly have been noticed and would be expected to produce spikes on the curve, yet it shows a relatively smooth and steady increase in average $\mathrm{CO}_{2}$ levels over time. No natural sources of $\mathrm{CO}_{2}$ have been identified that can explain both the quantity and the timing of the increase in atmospheric concentration measured at Mauna Loa and in related data.

One significant source of $\mathrm{CO}_{2}$ that does fit the Keeling Curve is the human combustion of fossil fuels. Since the beginning of the First Industrial Revolution in Great Britain during the mid- $18^{\text {th }}$ Century that transitioned the manufacturing of products from individual handcrafting to mass production using machines (Wrigley, 2018), humanity's use of fossil fuel as an energy resource has been growing. Steam from coal combustion was a major power source for machinery in early factories. By the early $20^{\text {th }}$ Century, most factory machines were powered by electricity, which also commonly used coal as a power source. The development of the internal combustion engine in the $19^{\text {th }}$ Century required petroleum and further increased the use of fossil fuel. Natural gas was adopted in the mid- $20^{\text {th }}$ Century as a widespread utility to replace manufactured gas. The increased use of fossil fuels to power our civilization (Fig. 2) precisely tracks the increase in atmospheric $\mathrm{CO}_{2}$ concentrations measured at Mauna Loa since 1957. This human-produced, or "anthropogenic" $\mathrm{CO}_{2}$ has raised GHG levels in the atmosphere and is causing climate change.

The carbon in fossil fuels is not part of the Earth's active carbon cycle but has been "sequestered" or isolated deep underground for tens or hundreds of millions of years as coal, petroleum, or natural gas. Human mining and drilling activities 


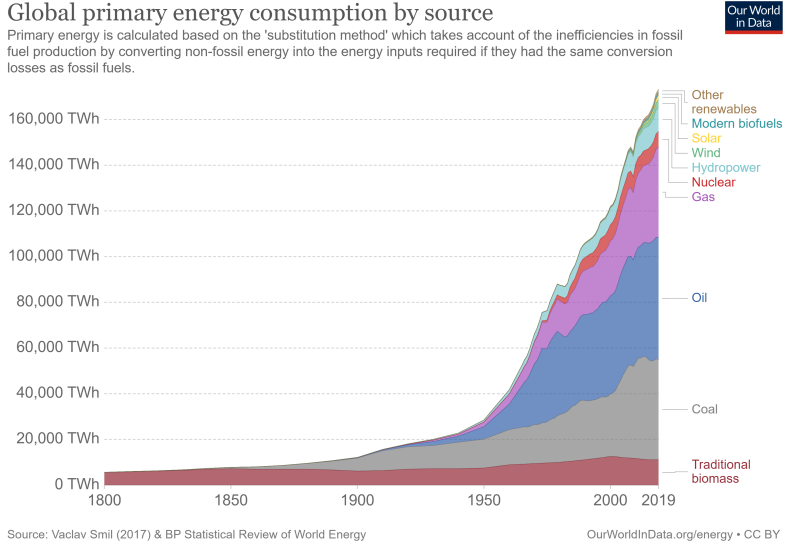

Fig. 2. Global energy consumption from 1800 to 2019 showing the dominance of fossil fuels. Source: Ritchie, H. "Energy" (open access) Published online at OurWorldInData.org. Retrieved from: https://ourworldindata.org/energy.

have brought this deep carbon to the surface. The $\mathrm{CO}_{2}$ released into the air by combustion adds the formerly sequestered carbon into the atmospheric GHG load and is steadily increasing the total global concentrations of $\mathrm{CO}_{2}$. Per unit of energy, coal produces the most $\mathrm{CO}_{2}$ as a combustion product, and natural gas the least, with petroleum in between (Soeder, 2021).

\section{Climite impacts}

Geological evidence discovered in the $19^{\text {th }}$ Century that the Earth had been through a series of major Ice Ages convinced scientists that the climate was not constant but had changed dramatically over the Earth's history. In seeking an explanation for the Ice Ages, a Swedish physicist and chemist named Svante Arrhenius hypothesized that changes in the concentration of heat-absorbing atmospheric gases might have been responsible. Professor Arrhenius was already well-known in scientific circles for formulating the theory of electrolytic dissociation (i. e., the breakdown of water into hydrogen and oxygen by an electrical current), and that work would earn him the 1903 Nobel Prize. Arrhenius constructed what many consider to be the first mathematically based climate model in an attempt to understand how changes in atmospheric carbon dioxide might affect global temperatures. The model consisted of a fairly concise and constrained series of mathematical calculations showing how variations in atmospheric $\mathrm{CO}_{2}$ concentrations could allow the Earth to warm or cool (Arrhenius, 1896).

The model calculated that the annual combustion of coal (around 500 million tons in 1896) would increase $\mathrm{CO}_{2}$ levels in the atmosphere by about one part per thousand per year. This figure is quite high because Arrhenius assumed that all of the $\mathrm{CO}_{2}$ combustion products would end up in the atmosphere, and he did not account for dissolution of the gas in seawater, incorporation into vegetation, and the increased chemical weathering of rocks. The Keeling Curve in Fig. 1 shows that the current, measured increase of $\mathrm{CO}_{2}$ in the atmosphere is about 2 ppm per year even with our much greater rates of fossil fuel combustion.

Multiple lines of evidence show that the average global
Separating Human and Natural Influences on Climate

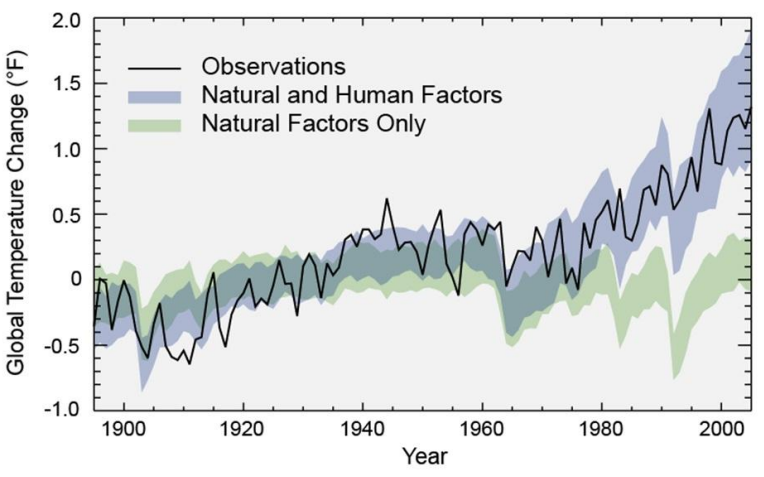

Fig. 3. Realizations from climate model scenarios showing global temperature trends with and without the influence of anthropogenic GHG. The solid black line represents observations. Source: U. S. Environmental Protection Agency public domain.

temperature has warmed by about one degree $\mathrm{C}$ since meteorological records began in the 1880s. Almost all of this temperature increase resulted from anthropogenic GHG and associated feedback mechanisms. Climate models indicate that global temperatures would have remained steady or even cooled slightly (Fig. 3) without the addition of human produced GHG (IPCC, 2013). As shown in Fig. 3, the "human induced" and "natural" factors began to diverge in the 1970s, when the human use of fossil fuels for energy rose sharply (refer back to the timeline in Fig. 2). This resulted in a substantial release of $\mathrm{CO}_{2}$ and other GHGs into the atmosphere as combustion products. It also marks the debut of "clean air" regulations that reduced the amount of particulate matter and aerosols emitted into the atmosphere that block sunlight and contribute to cooling.

Climate models predict that impacts from a warming atmosphere will affect the polar regions of the Earth first, especially the Arctic in a process called "Arctic acceleration" (IPCC, 2013). This has resulted in the loss of year-round sea ice on the Arctic Ocean, along with record high temperatures and wildfires in northern Siberia. The melting of the remaining terrestrial ice sheets and large glaciers in polar regions could result in the oceans rising as much as two meters above present sea level by the year 2100 (Bamber et al., 2019). If the entire ice volume in Greenland and Antarctica melts, the oceans could potentially rise by as much as 76 meters (250 feet) above present-day sea level (Poore et al., 2000). Large volumes of fresh water pouring into the oceans from melting ice caps also will affect ocean currents and influence the paths and intensity of many storms.

Sea level has been unstable throughout most of geologic time and coastlines are especially vulnerable to climate change. In the recent geologic past, sea levels were 4-6 meters (13-20 feet) above present-day levels about 125,000 years ago during the last interglacial period. Around 20,000 years ago at the peak of the most recent ice age, so much water was tied up in massive continental ice sheets that the sea level had

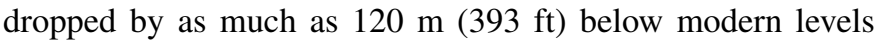
(Gornitz, 2009). Large areas of the present-day continental 
shelves were dry land, and fossilized mammoths are found on a regular basis in sea bottom sediments off the U. S. coast of New Jersey (Richards, 1962).

Higher levels of GHG in the atmosphere will trap more heat, and warmer air holds more moisture. This can result in more intense and prolonged droughts as the air takes up moisture, and larger and fiercer storms as the air releases that moisture as rain. Translating climate change into daily weather patterns is complex and challenging (Rapp, 2014). Nevertheless, the severity and frequency of droughts, especially those combined with heatwaves appear to be increasing (Derouin, 2021), along with the intensity of major storms. Changing climates steer powerful storms into locations that have little history of dealing with such weather, increasing the vulnerability of human populations (Tippett et al., 2016; Gensini and Brooks, 2018).

Events that include both extended droughts and excessively warm temperatures (i. e., heatwaves) have increased globally in frequency, duration, and severity in recent years. The pattern of occurrence of these combined drought-heatwave events is asymmetric with the northern hemisphere appearing to be more strongly affected (Mukherjee and Mishra, 2021). The peak temperatures of intense heat waves when amplified by high humidity pose serious threats to human health (Russo et al., 2017). The severe heat wave that struck western Russia and eastern Europe in 2010 reportedly killed an estimated 55,000 people. The combination of heat and humidity could potentially make some areas of the tropics and subtropics uninhabitable by humans before the end of the $21^{\text {th }}$ Century.

Over the past 5,000 years of recorded human history, and probably since agriculture was established some 10,000 years ago, people have tended to concentrate in climates with mean annual temperatures of approximately $13{ }^{\circ} \mathrm{C}\left(55^{\circ} \mathrm{F}\right)$. Climate change is projected to shift the geographical position of this favorable temperature zone significantly over the next fifty years (Xu et al., 2020). Up to a third of the global population (one to three billion people) may be experiencing mean annual temperatures greater than $29{ }^{\circ} \mathrm{C}\left(84{ }^{\circ} \mathrm{F}\right)$ by the late $21^{\text {st }}$ Century; such temperatures at present are primarily limited to the Sahara Desert. The most strongly affected regions are among the poorest in the world, where the ability to adapt is limited (Xu et al., 2020). These predicted temperature disruptions combined with sea level rise may displace many people and result in mass migrations to cooler, inland locations. The United Nations already has a term for this: climate refugees.

\section{Ending the use of fossil fuels}

There is no question that fossil fuels have been of great benefit to humankind. Our modern, technological society would not have been possible without the advances that came from the Industrial Revolution, the Age of Steam, and the invention of the railroad, steamship, automobile, airplane, electric light, electric motor, and a host of other devices. All of these either run on fossil fuel directly, like automobiles and jet aircraft, or indirectly through the use of electricity.

Fossil fuel technology has increased productivity, greatly reduced the time needed for people and goods to move around the world, and improved human health, comfort, and longevity. Coal, fuel oil and natural gas replaced wood for heating and cooking, sparing many forests. Cheap kerosene replaced increasingly rare and expensive whale oil as a lamp fuel for illumination in the late $19^{\text {th }}$ Century, eventually driving the whaling industry out of business (Harper, 1998). By performing work far more efficiently than human or animal muscles, fossil fuel-powered machines have allowed a much greater variety of people to carry out tasks that formerly required brute strength.

That being said, there are enormous downsides for continuing to use fossil fuel to power our technology. Climate change from GHG is the most obvious issue, but other problems abound. $\mathrm{CO}_{2}$ dissolves in seawater and forms carbonic acid, lowering the $\mathrm{pH}$ of the oceans and harming shelled creatures by literally dissolving them. Coal mining, especially surface or "strip" mining damages landscapes and watersheds, while underground mining is dirty and dangerous. Sulfur in coal can form sulfuric acid in the air to create acid rain. Coal ash contains toxic metals like mercury and selenium that can seep into groundwater. Oil spills can devastate ecosystems and create fire hazards, including one of the most serious disasters in North American history when a train carrying Bakken crude oil derailed in the Canadian town of Lac-Mégantic in 2013, caught fire and incinerated much of the town, killing 47 people (Campbell, 2018). Petroleum also emits volatile organic compounds, which can cause human health problems if inhaled or absorbed through the skin and react with sunlight to form photochemical smog. Many of the chemicals used in hydraulic fracturing ("frack") operations to produce gas and oil are toxic and potential leaks and spills are a concern (Soeder, 2021). In addition to being a strong GHG, leaking natural gas can also accumulate in confined spaces like basements and explode (Baldassare et al., 2014).

Many people do not realize just how pervasive the use of fossil fuels for energy has become. Despite hundreds of wind turbines and the sixty-year history of nuclear power, the United States, with the largest economy in the world, still obtains 80 percent of its primary energy from fossil fuels. The second largest national economy, that of China, obtains 86 percent of its energy from fossil fuels [(U. S. Energy Information Agency (USEIA), 2020]. Replacing these fuels with energy resources that emit zero GHG will be an enormous challenge.

In addition to GHG and climate change, another important reason to stop using fossil fuels is that they are a finite resource and unsustainable over the long term. Conventional supplies of natural gas in the United States were running low in the early 2000s, and plans were being made to import liquified natural gas (LNG) from North Africa and the Middle East. The shortages pushed gas prices to unprecedented highs, providing an incentive for companies to invest in new technology to drill and frack shale wells (Soeder, 2017). Shale gas proved to be amazingly successful, and by 2009, the United States had surpassed Russia as the largest gas producer in the world. The LNG import terminals were turned into export terminals and the U. S. began exporting shale gas to Europe. Make no mistake, however, this is only a temporary reprieve. Shale gas reserves are large but not infinite, and in a few years, or 
decades at most, they will be running low.

Petroleum resources also improved as part of the shale gas revolution. As natural gas turned from a shortage into a glut, prices fell sharply. American industry turned to fracking oilrich shale formations, like the Bakken in North Dakota and the Eagle Ford in Texas to produce the more profitable and easier to export liquid hydrocarbons (Soeder and Borglum, 2019). This so-called "tight oil" from shale quickly pushed North Dakota into the number two spot for oil production in the U. S., behind only Texas. The United States surpassed Saudi Arabia in 2013 to become the largest petroleum producer in the world. Like shale gas, however, tight oil resources are large but not infinite, and the U. S. leadership position is only temporary.

While fossil fuel resources are still abundant and economies are strong, we should be working hard to develop new energy resources that can supply our technology and civilization without damaging the climate. Waiting until fossil fuel becomes scarce and economies totter under climate change runs the risk of bad decisions being made in haste. Carbonneutral energy sources like wind turbines, solar photovoltaics, and nuclear power have made inroads, but much more needs to be done. Hydropower is carbon neutral, but nearly all of the large rivers in the world have been dammed. Ocean energy from waves and tides is conceptual, but so far impractical. Exotic energy like nuclear fusion or antimatter will be wonderful if and when they happen, but the climate problem must be solved soon using the technology currently available.

In addition to renewables like wind and solar, existing options include biofuels, geothermal, and new nuclear fission technologies. All are technically feasible or close to it. Biogas in particular is readily made by microbes from virtually any waste organic matter and can directly replace natural gas. Both are methane, and biogas tied to the carbon cycle is carbonneutral compared to the fossil carbon in natural gas. Genetic engineering of the microbes could perhaps be used to improve their efficiency.

Geothermal holds great promise for carbon-free energy. The heat of the Earth can be tapped to make steam and drive electrical turbines. In the past, this was restricted to regions with hot springs, geysers, and active volcanoes. However, new technology adapted from shale gas called engineered (or "enhanced") geothermal systems (EGS) proposes to drill wells to great depths to reach the hot rock that exists everywhere deep in the Earth [U. S. Department of Energy (USDOE), 2016]. Hydraulic fractures through the deep, hot rocks would connect two wells, allowing fluids to be circulated downhole to extract heat and return it to the surface. A field experiment in Utah is underway at this writing to test the concept. Creating fractures at great depths in hot rocks has challenges, however, not the least of which is that forcing fluids to flow through deep fracture systems under pressure could potentially induce earthquakes. An alternative EGS design called solarassisted geothermal energy or SAGE uses shallower wells to circulate water heated by a surface solar loop through porous sedimentary rock, where the rock mass itself acts to accumulate, store, and supply the heat for use.

In addition to biogas and geothermal, a third non-carbon energy option is advanced nuclear fission reactor technology, using a thorium-based fuel cycle [International Atomic Energy Agency (IAEA), 2005]. These designs typically incorporate molten salt as the coolant and heat exchanger and the reactor vessels are relatively small in size. Small reactors made in a factory setting can be certified automatically during the manufacturing process instead of undergoing the tedious and expensive inspection of individual welds and fittings on-site as each reactor is being constructed. A number of small, standardized reactors can be connected in parallel to produce greater thermal energy output.

A goal of these new energy technologies is to replace fossils fuels as heat sources in thermoelectric power plants. Heat is required to boil water and create steam that turns a turbine and generator, but the source of the heat makes no difference to the boilers. Replacing a coal fire with geothermal or nuclear heat, and natural gas with biogas would allow existing electrical facilities to generate power while becoming carbon neutral. This has substantial economic advantages over renewables like wind and solar, which require completely new infrastructure to generate power and transmit it to the grid. By allowing electrical utilities to retain investments in existing power plants and transmission lines, the replacement of fossil fuel with non-carbon heat sources in thermoelectric plants can ensure a rapid transition to carbon-free electricity. Once the electrical generating sector has been freed of fossil fuel dependence, the transportation and manufacturing sectors will follow.

\section{Mitigation of GHG}

What can be done in the immediate future to deal with climate change? It will obviously take some time to convert or replace electrical generating infrastructure with carbon neutral options, and it may take even longer for certain industrial processes like steel making and cement manufacturing to find climate-friendly alternatives. The most common mitigation techniques being considered world-wide are 1) capturing emissions to reduce or eliminate anthropogenic inputs of GHG into the atmosphere to keep things from getting worse, and 2) removing $\mathrm{CO}_{2}$ directly from the air to help offset the worst aspects of climate change.

The first approach involves capturing $\mathrm{CO}_{2}$ combustion products at the source before they reach the atmosphere in a process known as carbon capture and storage (CCS). Sometimes a desirable use can be found for the captured carbon dioxide to help improve the economics, and this process is referred to as carbon capture, utilization and storage (CCUS). Both terms appear in the literature (USDOE, 2012). Reducing existing $\mathrm{CO}_{2}$ levels in the atmosphere by removing the gas directly from the air is called Direct Air Capture (DAC). Ideas for this range from planting trees and fertilizing the oceans to constructing giant mechanical air handler units that remove $\mathrm{CO}_{2}$ from the atmosphere by processing cubic kilometers of air per day (Kramer, 2020).

Schemes to deal with global temperature instead of GHG are called "geoengineering" and include things like spreading soot high in the atmosphere to block sunlight and cool the 
planet. These ideas are generally considered high-risk because the consequences of large-scale planetary engineering are poorly understood and could be dire.

\section{CCUS}

CCS and CCUS work by capturing $\mathrm{CO}_{2}$ in the smokestack before it can be vented into the atmosphere. Current designs are bulky and limited to stationary sources of carbon dioxide, such as power plants. The two primary existing processes for capturing $\mathrm{CO}_{2}$ are either chemical or cryogenic, although experiments with membrane separation may yield another potential approach (Songolzadeh et al., 2014). Chemical methods use materials like amines to absorb carbon dioxide directly from the flue gas and release it elsewhere for storage by changing either the pressure or temperature. So-called "pressure swing" amine adsorption is the most common technology presently in use, although others are in development. The cryogenic method works by freezing the $\mathrm{CO}_{2}$ out of the air. Carbon dioxide forms "dry ice" at temperatures that are cold ($109.3^{\circ} \mathrm{F}$ or $-78.5^{\circ} \mathrm{C}$ ), but still much higher than temperatures required to liquefy other gases like nitrogen or oxygen. Water ice also forms at these temperatures however, and any humidity in the flue gas can cause ice build-up. Neither process is free - the energy costs for carbon capture are 15 percent or more of a power plant's output (Kramer, 2018). Any opportunity to utilize the captured $\mathrm{CO}_{2}$ for generating revenue helps improve the economics (USDOE, 2012).

Unfortunately for the revenue end, there is not much industrial demand for carbon dioxide at the moment. Most industries that do use the gas purchase it from $\mathrm{CO}_{2}$ wells in naturally occurring underground reservoirs at a cost of $\$ 30$ to $\$ 40$ per ton (Kramer, 2018). Captured carbon dioxide from flue gases costs about $\$ 100$ to $\$ 200$ per ton depending on the method used. This price disparity has hobbled CCUS. However, because both the chemical and cryogenic carbon capture processes are $\mathrm{CO}_{2}$-specific, the captured product is purer than the natural reservoirs. Where this matters, for instance in applications like carbonated beverages, the captured $\mathrm{CO}_{2}$ is favored. The other main use for captured $\mathrm{CO}_{2}$ at present is to re-pressurize depleted petroleum reservoirs for enhanced oil recovery (EOR) operations. This is done primarily because the $\mathrm{CO}_{2}$ is available for oilfield operations but is also worth a tax credit since the $\mathrm{CO}_{2}$ remains sequestered underground. However, the production of more petroleum to be burned may offset any net carbon storage.

One of the main problems with the "utilization" part of CCUS is transporting the captured carbon dioxide from the source to the location where it will be used. If a coal-fired power plant is located relatively close to an enhanced oil recovery area, then a fairly short pipeline can be installed to transport the gas. A CCUS project called Petra Nova is such a case. A joint venture between NRG Energy and JX Nippon Oil \& Gas Exploration, it is designed to capture about 90 percent of the $\mathrm{CO}_{2}$ emissions from a coal-fired powerplant near Houston, Texas and transport the gas via pipeline to Hilcorp's West Ranch oil field, located near Vanderbilt, Texas some $130 \mathrm{~km}$ (80 miles) away for use in EOR operations. Pl-

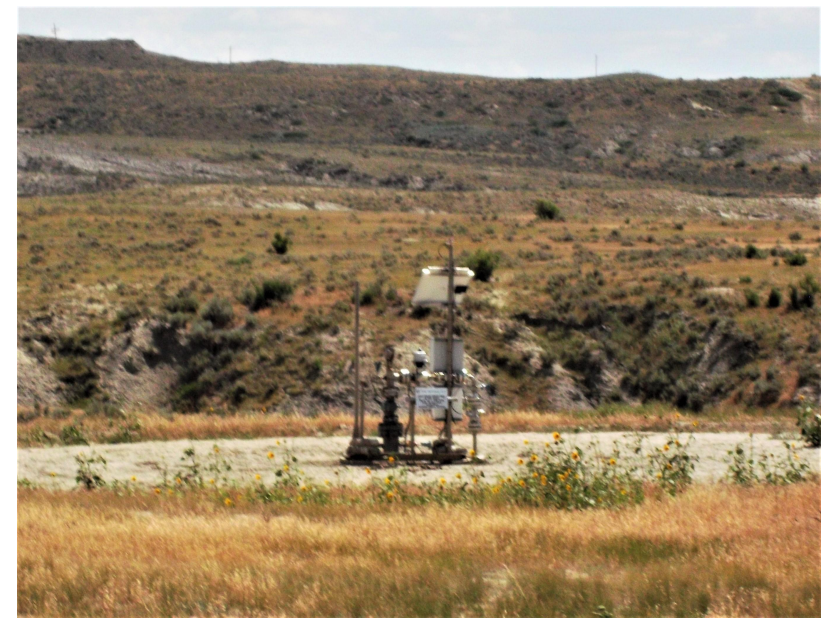

Fig. 4. Wellhead in the Salt Creek oilfield of Wyoming, USA, with infrastructure for injection of $\mathrm{CO}_{2}$ to carry out Enhanced Oil Recovery operations. Source: Photographed by Dan Soeder in 2019.

ans call for the eventual sequestration of some 1.4 million metric tons of $\mathrm{CO}_{2}$ annually (https://www.nrg.com/casestudies/petra-nova.html). The project became operational in January 2017 but was shut down temporarily in 2020 because of low oil prices brought on by travel restrictions during the COVID-19 pandemic.

Denbury Resources is one of the primary companies in the United States using carbon dioxide for EOR. The company has a network of $\mathrm{CO}_{2}$ pipelines in the U. S. Gulf Coast states of Texas, Louisiana, and Mississippi to transport the gas from both natural and industrial sources to EOR fields, and also in Wyoming to transport $\mathrm{CO}_{2}$ to the Cedar Creek Anticline in Montana for EOR operations (Denbury, 2020).

The Denbury pipeline in Wyoming connects to a $\mathrm{CO}_{2}$ pipeline established a decade ago by the state. Since 2012, the U. S. state of Wyoming has been pursuing an effort known as the Wyoming Pipeline Corridor Initiative to connect carbon dioxide sources with old oilfields requiring EOR for economical production (https://www.eoriwyoming.org/). The current infrastructure connects carbon capture at two coal-fired powerplants, Shute Creek and Lost Cabin, with a pipeline that runs across the state to supply $\mathrm{CO}_{2}$ to several oilfields, including Salt Creek. The carbon dioxide injection infrastructure on a well in the Salt Creek field is shown in Fig. 4.

Other uses for captured carbon dioxide include injection into gassy coal seams to improve the recovery of coalbed methane (Hamelinck et al., 2002), although this has been constrained by the low gas prices resulting from abundant shale gas. Shale gas itself can be recovered more efficiently through the use of $\mathrm{CO}_{2}$ injection, although in the absence of field tests, this has only been investigated theoretically and in laboratory experiments (Hong et al., 2016). Enhanced methane recovery from both shale and coal makes use of the fact that $\mathrm{CO}_{2}$ adsorbs more strongly to the organic matrix in these formations than methane, with each $\mathrm{CO}_{2}$ molecule displacing three $\mathrm{CH}_{4}$ molecules.

The efficiency of carbon capture can be improved. Coal burned in air produces a carbon dioxide concentration in the 
flue gases of generally less than 15 percent (Songolzadeh et al., 2014). The chemical absorbents are not very efficient at capturing such low concentrations, but if coal is burned in pure oxygen the level of $\mathrm{CO}_{2}$ in the combustion gases can be increased to more than 80 percent. The high $\mathrm{CO}_{2}$ concentrations in flue gases produced by this "oxy-combustion" process can be captured more easily, although providing an oxygen supply adds additional costs. The capture efficiency is improved, but not necessarily the economics.

\section{DAC}

DAC is the term for removing excess $\mathrm{CO}_{2}$ directly from the atmosphere (Kramer, 2020). There are essentially two approaches: biological and mechanical. Biological $\mathrm{CO}_{2}$ removal uses photosynthetic plants such as trees or marine algae to capture the $\mathrm{CO}_{2}$ during the growth cycle followed by various methods to sequester it. The carbon must be kept out of the atmosphere after the plants die or there is no net GHG reduction. Harvesting wood and turning it into durable products like furniture or construction lumber will keep the carbon sequestered for decades to centuries, but once that wood rots or burns, the carbon dioxide will return to the air. It would also require billions or possibly trillions of trees to make a significant difference in the concentration of atmospheric $\mathrm{CO}_{2}$, and there are limits to the amount of land that is both available and suitable for planting and growing trees.

On a somewhat larger scale, fertilizing vast stretches of ocean by adding nitrates and iron to seawater will create immense blooms of photosynthetic green algae that remove $\mathrm{CO}_{2}$ from the air as they develop (Powell, 2008). The abundant algae then become a food source consumed by various sea creatures ranging from krill to whales, and the carbon is sequestered as fecal pellets that sink to the deep seafloor. Once it reaches the abyssal seabed, the carbon will stay isolated from the atmosphere for millennia.

Mechanical DAC removes $\mathrm{CO}_{2}$ from the atmosphere by employing what are known as "artificial trees" (Kramer, 2018). These devices process enormous volumes of air and use either chemical or cryogenic methods to capture the $\mathrm{CO}_{2}$, which is then sequestered. An advantage of the artificial tree systems is that they can be located in deserts, tundra, high mountain peaks, and other places that are unsuitable for growing living trees.

The artificial trees have substantial capital and operating costs because huge machinery is required to process the massive quantities of air necessary to capture reasonable amounts of $\mathrm{CO}_{2}$. Mechanical DAC is technically challenging: even though $\mathrm{CO}_{2}$ concentrations in the atmosphere have alarmed climate scientists by reaching a record high of more than $400 \mathrm{ppm}$, from a chemical engineering standpoint this is still an extremely low concentration to remove from a mixture of gases. Nevertheless, a DAC system is currently operating in Switzerland and others are in the design stage (Kramer, 2020). The cost of $\mathrm{CO}_{2}$ obtained from DAC by artificial trees ranges from $\$ 100$ to $\$ 600$ per ton. Although the economics are not yet competitive, proponents of DAC claim they will eventually make a profit.

\section{Options for GHG isolation}

Once carbon dioxide is captured, it must be stored in a manner that keeps it sequestered or isolated from the atmosphere (USDOE, 2012). There are a number of ways to accomplish this, each of which has pros and cons. The three main storage options are 1) geologic storage deep underground, 2) terrestrial storage in soils, vegetation, or manufactured materials on the surface, and 3) ocean storage in deep seawater (Ajayi et al., 2019).

Geologic storage seeks to place $\mathrm{CO}_{2}$ deep underground to keep it isolated. A number of different ideas are under consideration (USDOE, 2012), but the most popular options include:

- Depleted conventional oil and gas fields. These are known to have held oil and natural gas underground over geologic time periods and could also potentially store $\mathrm{CO}_{2}$ within the existing trap and seal. Depleted fields have existing wells that can be used for injection, and the injected $\mathrm{CO}_{2}$ can often be used to recover additional oil from the reservoir. However, old wells may have deteriorated cement and corroded casing, potentially allowing the $\mathrm{CO}_{2}$ to leak and migrate back to the surface (Watson and Bachu, 2009).

- Coal seams. The organic carbon that makes up the bulk of coal is capable of adsorbing or chemically attaching itself to $\mathrm{CO}_{2}$, providing a significant amount of storage. In fact, coal adsorbs $\mathrm{CO}_{2}$ about three times more strongly than methane, and the flammable methane may be displaced into existing mines where it becomes a hazard. As such, much of the focus has been on "unmineable" coal seams that are too deep or too thin to mine. The adsorption process can also cause the coal to swell, cutting off flow paths and making it difficult for large amounts of $\mathrm{CO}_{2}$ to enter the seam.

- Depleted gas shales. Hydraulically fractured gas shales may provide another option for $\mathrm{CO}_{2}$ storage once they are depleted (Levine et al., 2016). Like conventional oil and gas reservoirs, depleted shales would have existing wells and empty pore space for $\mathrm{CO}_{2}$, and like coal, the organicrich shale would also adsorb a component of the gas. However, it is unclear when production companies would declare a shale gas well to be "depleted," as these are known to produce low but steady amounts of natural gas for decades. In addition, the possible effects of hydraulic fracturing on the integrity of shale for $\mathrm{CO}_{2}$ storage are unknown.

- Deep saline aquifers. Saltwater brines in porous rocks at great depths can hold $\mathrm{CO}_{2}$ in solution under high pressure. One advantage is that holding the gas in solution requires less pore space than holding it as a separate phase. The downside is that drilling to the depths of these aquifers is expensive, and there are few existing wells. Also, carbon dioxide in solution forms a weak acid, and the potential effects of this over time on wellbore cement, downhole tubulars, and the formation itself are unclear.

- Basaltic lava rocks. These rocks weather easily and release calcium and magnesium cations which react 
chemically with $\mathrm{CO}_{2}$ and turn it into the solid carbonate minerals calcite and magnesite. A major advantage of this process is that once converted to a solid phase, the $\mathrm{CO}_{2}$ is essentially immobilized, removing concerns about it leaking back to the surface. Basalts are often highly fractured, and it is not clear how well the $\mathrm{CO}_{2}$ will be contained within the rock while being converted to mineral form. The required residence time appears to be quite short, however; recent experiments in Iceland found that $\mathrm{CO}_{2}$ injected into basalt formed carbonates in as little as two years (Matter et al., 2016).

Terrestrial storage of $\mathrm{CO}_{2}$ seeks to store the gas in soils or vegetation, or to utilize $\mathrm{CO}_{2}$ in construction materials that will keep it out of the atmosphere for an extended period of time. Storage in terrestrial ecosystems uses soils and biomass in forests to sequester $\mathrm{CO}_{2}$. Particular land types of interest include locations that have been surface mined, such as coal strip mines, and later reclaimed. Reclaimed land often lacks significant carbon in the soil and may provide an opportunity to store carbon in both soils and vegetation (Litynski et al., 2006). Other ideas for terrestrial storage include:

- Concrete. Concrete emits substantial amounts of $\mathrm{CO}_{2}$ during manufacture, so using it to sequester $\mathrm{CO}_{2}$ helps offset this. The material that holds concrete together is cement, made by heating crushed limestone, clay and other ingredients in a kiln to more than $1,425{ }^{\circ} \mathrm{C}(2,600$ $\left.{ }^{\circ} \mathrm{F}\right)$. The calcium carbonate making up limestone dissociates under high temperature into $\mathrm{CO}_{2}$ and calcium oxide $(\mathrm{CaO})$ through a process called calcination. The $\mathrm{CaO}$ is needed for the cement, but $\mathrm{CO}_{2}$ is a waste product and vented to the atmosphere. In addition, if the kiln is heated by fossil fuel combustion (which most are), this is also a source of $\mathrm{CO}_{2}$ emissions. Increasing urbanization and construction of infrastructure has made the global production of concrete responsible for approximately $8.6 \%$ of all anthropogenic $\mathrm{CO}_{2}$ emissions (Miller et al., 2016). When concrete cures, $\mathrm{CO}_{2}$ reacts with the $\mathrm{CaO}$ in the cement to re-form calcite. This is similar to the basalt process chemically, but more rapid. Several processes can be used to introduce $\mathrm{CO}_{2}$ into the cement mixture to enhance this reaction, sequester the $\mathrm{CO}_{2}$, and make the concrete stronger. Combined with mitigation of $\mathrm{CO}_{2}$ emissions during the production process, boosting the $\mathrm{CO}_{2}$ content of cured concrete could make it more carbon neutral. Once locked down in the concrete, the $\mathrm{CO}_{2}$ stays in place for long time periods. Even if the concrete eventually weathers and crumbles, the calcite minerals are relatively stable and generally remain intact.

- Sealed greenhouses. The goal here is to enhance plant growth. The plants being grown would be those that normally see an extended use as human building materials to keep the $\mathrm{CO}_{2}$ from re-entering the atmosphere. Various exotic hardwoods and other desirable plant-based construction materials like bamboo could be grown quickly in greenhouse containing a $\mathrm{CO}_{2}$-enriched atmosphere. As long as these products do not rot or burn, the $\mathrm{CO}_{2}$ will stay sequestered.
- Microbial conversion to methane. This idea is to provide $\mathrm{CO}_{2}$ to cultures of anaerobic bacteria to consume and convert to methane gas. The methane would then be used for combustion, substituting for natural gas, and displacing additional fossil carbon.

- Microbial conversion to useful materials. Variations on the microbial conversion theme include using microbes to convert $\mathrm{CO}_{2}$ to calcite, which may be faster than inorganic mineral conversion. Other ideas are to use genetically engineered microbes to create graphene, carbon fiber, carbon nanotubes, or other desirable materials from $\mathrm{CO}_{2}$.

- Chemical conversion to fuels or materials: Chemical engineering technology can be used to convert $\mathrm{CO}_{2}$ into ethylene, which can then be made into a host of materials ranging from gasoline to plastic bags. The economics of these processes remain uncertain.

Ocean storage of $\mathrm{CO}_{2}$ involves the injection of carbon dioxide into seawater at depths greater than one kilometer from ships, pipelines, or offshore platforms. At these depths, the $\mathrm{CO}_{2}$ has a greater density than water and will dissolve and disperse without coming to the surface (Herzog et al., 2000). However, given the concerns about ocean acidification by $\mathrm{CO}_{2}$ inputs from the atmosphere, there could be potentially major environmental impacts on deep sea biota near concentrated $\mathrm{CO}_{2}$ injection points (Seibel and Walsh, 2003). Ocean storage at present remains in the research stage without any actual field tests (Ajayi et al., 2019).

\section{Discussion}

Compared to the 34 billion metric tons of anthropogenic $\mathrm{CO}_{2}$ released globally to the atmosphere in 2020 , the annual amount of $\mathrm{CO}_{2}$ captured and stored by all of humanity is only about 5 million metric tons. Clearly, we must do better.

There is an energy cost for using CCS, which translates into a real monetary cost (Kramer, 2018). Substantial research efforts over the past few decades have sought to find uses for captured fossil carbon that will help improve the economics of CCS, but success has been limited. Most consumers worldwide are less than enthusiastic about paying a higher price for electric power with CCS, even if it is environmentally responsible and would mitigate climate change. Fossil energy is cheap and has been cheap for a long time, leading people to expect that it will continue to be cheap. One of the major logistical challenges of addressing climate change will be convincing the average citizen of the world that higher energy costs are necessary to preserve the environment.

Renewables and nuclear power are more expensive than fossil energy. Adding CCS to fossil fuel combustion will likewise raise the cost of fossil energy. This is not necessarily a bad thing, because higher fossil energy prices will make renewables and nuclear more cost competitive while also reducing the use of fossil fuel. More expensive energy in the future must be viewed as a necessary price paid to prevent a climate catastrophe. It is in fact a bargain compared to the cost of human suffering, the displacement of climate refugees from rising seas, the destruction of infrastructure by drought, heat, 
or violent storms, and the disruption to the global ecosystem and environment under business-as-usual.

The social cost of carbon (SCC) is an important economic index for developing climate policies (Nordhaus, 2017). It is used for estimating the cost-benefit ratio of reducing GHG emissions and addressing climate change. The SCC is currently estimated at $\$ 51 \mathrm{USD}$ per ton of $\mathrm{CO}_{2}$ or equivalent GHGs. The challenge for policy makers is to decide if this cost is worth the environmental gain. Citizens might be better off in a lower-cost, higher GHG world versus the poorer societies that will result from the expense of aggressively reducing GHG concentrations. However, if the SCC is expanded to include more intangible things like the loss of ecosystem services due to climate change, or rising food costs because of drought, the true environmental gains from GHG reductions can be better understood.

In addition to cost, one of the physical concerns about storing carbon dioxide in geologic formations is ensuring that it does not find its way back to the surface and atmosphere. Natural and induced fractures might provide flowpaths, or deteriorated cement and steel casings in old wells may allow $\mathrm{CO}_{2}$ to migrate upward (Watson and Bachu, 2009). The $\mathrm{CO}_{2}$ itself, especially at depths where it is present in a supercritical state and chemically active may attack minerals in fractures, or quartz and carbonate cements in sedimentary rocks and create its own flowpaths.

The engineering methodology for assuring that injected $\mathrm{CO}_{2}$ stays put in geologic storage formations is known as Monitoring, Verification, and Accounting. This typically involves detailed numerical modeling to understand how plumes of $\mathrm{CO}_{2}$ might escape the seal or caprock on an underground reservoir and migrate upward. In partnership with the modeling work, detection technology is under development and testing to monitor $\mathrm{CO}_{2}$ in the subsurface and provide early warnings if any escapes (USDOE, 2012).

Storing captured $\mathrm{CO}_{2}$ as a solid calcite or magnesite mineral phase in basalt does away with most of the worries about it migrating back into the atmosphere (Snæbjörnsdóttir et al., 2020). Limestone is a sedimentary rock composed primarily of calcium carbonate, and there are vast limestone formations that have sequestered $\mathrm{CO}_{2}$ from the Earth's early, carbon dioxide-enriched atmosphere for hundreds of millions of years. Carbonate rocks are especially prominent in the early Paleozoic when atmospheric levels of $\mathrm{CO}_{2}$ were much higher.

Limestones are stable over geologic time periods and are nature's preferred method for storing $\mathrm{CO}_{2}$. This part of the carbon cycle is naturally self-regulated because an increase in atmospheric $\mathrm{CO}_{2}$ from erupting volcanoes, for example, will result in increased ocean acidification, which speeds up the chemical weathering of volcanic rocks like basalt. The weathered rocks release more calcium and magnesium ions into seawater, and either organic or inorganic chemical reactions precipitate the $\mathrm{CO}_{2}$ as calcite or magnesite. These natural feedback mechanisms have regulated atmospheric and oceanic chemistry for millions of years. Our current dilemma stems from the fact that the human input of fossil carbon dioxide into the atmosphere has occurred over a timespan of only 200 years, which is far faster than the Earth can react to regulate it.

Fortunately, there is no shortage of basalt deposits that could store $\mathrm{CO}_{2}$. Basalt is one of the most common rocks on Earth, and makes up the crust under the oceans, along with the bulk of the Hawaiian Islands, Japan, Iceland, the Aleutians, and many other islands. The Mid-Ocean Ridge system is a vast, subsea mountain chain that encircles the planet and is made up almost entirely of basalt. Land deposits include the Columbia River basalts of the western U. S., and the Deccan Traps of India.

We cannot wait for nature to deal with climate change. The human use of fossil fuel over the past two centuries has disrupted the carbon cycle, and climate change is upon us. It is important to recognize that the climate system has a large amount of inertia. Like a gigantic ship that continues moving long after the engines are stopped, even if GHG emissions were ended tomorrow the momentum from our emissions to date will still carry us forward into climate change. Some authors claim that the situation is actually much worse than generally realized, and our current efforts are woefully inadequate to repair the damage done before we cross a threshold into a "ghastly" future (Bradshaw et al., 2021). The solution is to look at the total environment, including climate, and come up with a new path to set us on a different course.

So what is to be done? Two things: 1) we will have to adapt to climate change because it is coming whether we like it or not, and 2) we must switch energy sources as soon as possible away from fossil fuel to avoid making things worse. CCS or CCUS are good, short-term options, but in the long run, we need energy sources that are far more climate friendly. Right now, those are wind and solar, but both are intermittent power sources and have issues with energy storage. Many brilliant people are working on batteries, hydrogen, compressed air, and pumped water as means to store energy. All of these work, but most are inefficient.

Potentially available soon are new nuclear technology and engineered geothermal systems, possibly including a shallower, solar-assisted design. These could directly replace fossil fuel heat sources in thermoelectric power plants and allow utility companies to go carbon-free while preserving existing infrastructure. The technologies are in various stages of development, but at present they are not a top priority for public energy research funding, although they should be. Natural gas can be directly replaced with biogas methane, a fuel that is both carbon-neutral and sustainable. Cleaner energy will be more expensive, and consumers world-wide must be convinced that preserving the environment is worth the extra cost. Policy options like a tax on fossil carbon might be required to influence the economics and successfully make the switch (Soeder, 2021).

It is critically important for policy makers to understand that clever people will find creative ways to bypass overly complicated or poorly constructed policy. For example, a 2009 European Union directive to promote renewable energy resulted in biomass becoming the second largest source of renewable electricity in the U. K. However, much of the "biomass" burned in British power plants consists of wood harvested mechanically from U. S. forests, processed into pellets 
in American factories, and shipped across the Atlantic Ocean to the U. K. (Dunne, 2021). Although promoted as carbon neutral, the fossil energy used in the harvesting, processing, and transport steps ensures that it is not.

Switching energy sources is not easy and has been the subject of two documentary films produced by Dr. Scott Tinker at the University of Texas (https://switchon.org/). Despite the challenges, the serious potential risk to climate demands that humanity switch from fossil fuels to non-GHG renewables and do it soon. Any fossil fuel combustion that remains during the transition period must be equipped with CCS. We can no longer allow GHG emissions to waft unchecked into the atmosphere.

A final, crucial ingredient is to not give up hope. Human ingenuity and engineering talent in the $19^{\text {th }}$ and $20^{\text {th }}$ Centuries gave us hundreds of amazing inventions like automobiles, aircraft, telephones, lightbulbs, movies, satellites, and computers, to name just a few. Surely human ingenuity and engineering talent in the $21^{\text {st }}$ Century can give us sustainable, climate friendly sources of energy that will not destroy the planet.

\section{Conclusions and recommendations}

The human use of fossil fuels over the past two centuries has raised the level of GHG in the atmosphere and resulted in climate change. No other source of GHG can account for this. The amount of climate change already set in motion will affect polar regions, causing ice cap melting and sea level rise. If fossil fuel use continues along a course of "businessas-usual", humanity can expect more killer heat waves, severe storms, and serious droughts.

We must end our addiction to fossil fuels, and replace these with sustainable, non-GHG emitting energy sources. However, the cheapest electricity at present is produced by the combustion of fossil fuels like natural gas and coal without carbon capture (Soeder, 2021). This must change. Non-carbon energy, carbon-neutral energy and fossil fuel combustion with CCS are all physically possible. The technology exists for all of these, and in fact the capture and underground storage of $\mathrm{CO}_{2}$ is less technically challenging to the oil and gas industry than the exploration, production, and refining of petroleum.

Our current conundrum is not that renewable, sustainable, non-GHG emitting forms of energy are too expensive. It is that fossil fuel is too cheap. The price of the fuel does not include the cost of climate disruptions resulting from the combustion products freely escaping up a smokestack. It is challenging under these circumstances for sustainable energy resources to compete with fossil energy on cost. Achieving economic parity will require fossil fuel to become more expensive while noncarbon energy grows cheaper.

Barring any sudden, unforeseen technology breakthroughs, carbon capture should be implemented worldwide on fossil fuel combustion whenever possible. This will have the double benefit of preventing additional GHG emissions into the atmosphere, while also raising the cost of fossil fuel, making it more price competitive with renewables and encouraging conservation. Because energy economics are driven by a combination of technology and policy, options like a carbon tax on fossil fuels combined with tax credits for renewables will almost certainly be required to make the economics viable (Soeder and Borglum, 2019).

The switch from fossil to non-GHG energy must be made soon. Publicly-funded research should focus on advancing engineered geothermal energy and new nuclear energy technology. Both of these are fairly close to commercial status and because they are not location-specific or intermittent like wind and solar power, they can directly replace existing fossil fuel heat sources in thermoelectric power plants. The ability to retain existing electrical infrastructure by simply replacing the heat source used to make steam should be very attractive to most utility companies.

Geothermal needs to overcome the induced seismicity problem resulting from fluid injection into deep, fractured rocks in an EGS configuration. Perhaps the shallower SAGE option that uses unfractured, porous sedimentary rocks for the storage of solar heat might be more applicable to many locations. EGS is currently receiving a modest level of research support but this should be expanded substantially to resolve the engineering details and produce commercial designs. The sooner these are available, the sooner they can be implemented.

New nuclear technology is in limbo because of outdated regulations that require the on-site inspections of reactors under construction. Many new, standardized reactor designs could be manufactured in very short order if inspection, testing, and certification could be performed on the factory floor and allow certified designs to be manufactured as run of the mill products. Another major issue with nuclear technology, at least in the United States, is the disposal of high-level radioactive waste. Despite decades of battle over a proposed location for a permanent waste repository, the issue is far from resolved. Yucca Mountain in Nevada appeared to be a technically-viable site but ran into major political problems after substantial amounts of money had been spent to investigate and characterize it. Ending the Yucca Mountain Project may have been politically expedient, but it did not solve the nuclear waste issue. Utility companies would be foolish to invest in new nuclear technology if there is no clear answer for what to do with the waste. This uncertainty must be resolved and soon.

If we agree as a society that fossil fuel must be replaced, international cooperation and uniform policies at the level of national governments will be required to create the laws, taxes, and tax credits to make this work. A simple policy like a tax on carbon emissions and a credit for carbon capture might be enough to incentivize energy companies to add CCS, or switch to non-GHG forms of energy. Monetary penalties and benefits are proven methods for adjusting both personal and corporate behavior. Convincing energy producers that fighting climate change has specific cost advantages can move this forward.

Climate change from GHG is underway. We cannot stop it, but we can keep it from becoming far worse. The world must act together because this is a global problem. A combination of CCS, DAC, new energy technology, conservation, and better environmental stewardship can help humanity and ecosystems across the planet avoid the worst aspects of climate change. 
But we must act boldly, and we must act soon.

\section{Acknowledgement}

The author thanks Dr. Zhang Liwei of the Chinese Academy of Sciences for the invitation to contribute this paper. Thanks are also directed to the two anonymous reviewers and the editor for their technical comments that helped improve the manuscript.

Open Access This article is distributed under the terms and conditions of the Creative Commons Attribution (CC BY-NC-ND) license, which permits unrestricted use, distribution, and reproduction in any medium, provided the original work is properly cited.

\section{References}

Ajayi, T., Gomes, J. S., Bera, A. A review of $\mathrm{CO}_{2}$ storage in geological formations emphasizing modeling, monitoring, and capacity estimation approaches. Petroleum Science, 2019, 16: 1028-1063.

Arrhenius, S. On the influence of carbonic acid in the air upon the temperature of the ground. Philosophical Magazine and Journal of Science (London, Edinburgh, and Dublin), 1896, 5/41(251): 237-276.

Baldassare, F. J., McCaffrey, M. A., Harper, J. A. A geochemical context for stray gas investigations in the northern Appalachian Basin: Implications of analyses of natural gases from Neogene-through Devonian-age strata. American Association of Petroleum Geologists Bulletin, 2014, 98: 341-372.

Bamber, J. L., Oppenheimer, M., Kopp, R. E., et al. Ice sheet contributions to future sea-level rise from structured expert judgment. Proceedings of the National Academy of Sciences of the United States of America, 2019, 116(23): 11195-11200.

Bradshaw, C. J. A., Ehrlich, P. R., Beattie, A., et al. Underestimating the challenges of avoiding a ghastly future. Frontiers in Conservation Science, 2021, 1: 615469

Campbell, B. The Lac-Mégantic Rail Disaster: Public Betrayal, Justice Denied. Toronto, Canada, James Lorimer \& Company, 2018.

Denbury, Inc. 2020 Annual Report on Form 10-K, Denbury Inc. Plano, Texas, 2020.

Derouin, S. Simultaneous drought and heat wave events are becoming more common. Eos, 2021, 102.

Dunne, D. Biomass power: Is the UK's second-largest source of renewable energy sustainable? The Independent, Sunday 21 February 2021.

Gensini, V. A., Brooks, H. E. Spatial trends in United States tornado frequency. NPJ Climate and Atmospheric Science, 2018, 1(1): 38.

Global Carbon Project, Supplemental data of Global Carbon Budget 2020 (Version 1.0) [Data set]. 2020 Global Carbon Project.

Gornitz, V. Sea level change, post-glacial, in Encyclopedia of Paleoclimatology and Ancient Environments, edited by V. Gornitz, Encyclopedia of Earth Sciences Series, Dordrecht, Netherlands, Springer, 2009.

Hamelinck, C. N., Faaij, A. P. C., Turkenburg, W. C., et al. $\mathrm{CO}_{2}$ enhanced coalbed methane production in the Netherlands. Energy, 2002, 27: 647-674.

Harper, J. A. Why the drake well? Pennsylvania Geology, 1998, 29(1): 2-4.

Herzog, H., Eliasson, B., Kaarstad, O. Capturing greenhouse gases. Scientific American, 2000, 282(2): 72-79.

Hong, L., Jain, J., Romanov, V., et al. Factors affecting the interaction of $\mathrm{CO}_{2}$ and $\mathrm{CH}_{4}$ in Marcellus Shale from the Appalachian Basin. Journal of Unconventional Oil and Gas Resources, 2016, 14: 99-112.

IAEA. Thorium fuel cycle-Potential benefits and challenges: Report IAEA-TECDOC-1450, Vienna, Austria, 2005.

IPCC. Climate Change 2013: The Physical Science Basis. Contribution of working group I to the fifth assessment report of the intergovernmental panel on climate change, edited by T.F. Stocker, D. Qin, G.-K., et al. Cambridge, U. K. and New York, NY, USA, Cambridge University Press, 2013.

Keeling, C. D., Bacastow, R. B., Bainbridge, A. E., et al. Atmospheric carbon dioxide variations at Mauna Loa Observatory. Hawaii, Tellus, 1976, 28(6): 538-551.

Kramer, D. Can carbon capture from air shift the climate change equation? Physics Today, 2018, 71(9): 26-29.

Kramer, D. Negative carbon dioxide emissions. Physics Today, 2020, 73(1): 45-51.

Kramer, R. J., He, H., Soden, B. J., et al. Observational evidence of increasing global radiative forcing. Geophysical Research Letters, 2021, 48(7): e2020GL091585.

Levine, J. S., Fukai, I., Soeder, D. J., et al. U. S. DOE NETL methodology for estimating the prospective $\mathrm{CO}_{2}$ storage resource of shales at the national and regional scale. International Journal of Greenhouse Gas Control, 2016, 51(8): 81-94.

Manabe, S., Wetherald, R. T. Thermal equilibrium of the atmosphere with a given distribution of relative humidity. Journal of the Atmospheric Sciences, 1967, 24(3): 241259.

Martin, P. E., Barker, E. F. The infrared absorption spectrum of carbon dioxide. Physical Review Journals, 1932, 41(3): 291-303.

Matter, J. M., Stute, M., Snæbjörnsdottir, S. Ó., et al. S. Rapid carbon mineralization for permanent disposal of anthropogenic carbon dioxide emissions. Science, 2016, 352(6291): 1312-1314.

McNeill, L. This Lady Scientist Defined the Greenhouse Effect but didn't Get the Credit. Washington D. C., USA, Smithsonian Magazine, 2016.

Miller, S. A., Horvath, A., Monteiro, P. J. M. Readily implementable techniques can cut annual $\mathrm{CO}_{2}$ emissions from the production of concrete by over $20 \%$. Environmental Research Letters, 2016, 11(7): 074029.

Mukherjee, S., Mishra, A. K. Increase in compound drought and heatwaves in a warming world. Geophysical Research Letters, 2021, 48(1): e2020GL090617.

Nordhaus, W. D. Revisiting the social cost of carbon. Proceedings of the National Academy of Sciences of the United States of America, 2017, 114(7): 1518-1523. 
Poore, R. Z., Williams Jr., R. S., Tracey, C. Sea level and climate. U. S. Geological Survey Fact Sheet 002-00, Reston, VA, pp. 2, 2000.

Powell, H. Fertilizing the ocean with iron. Oceanus Magazine. Woods Hole Oceanographic Institute, 2008, 46(1): 4-9.

Rapp D. Anthropogenic influences on climate change. In: Assessing Climate Change: Cham, edited by Rapp D., Switzerland, Springer Praxis Books, 2014.

Richards, H. G. Studies on the Marine Pleistocene: Part I. The Marine Pleistocene of the Americas and Europe, Part II. The Marine Pleistocene Mollusks of Eastern North America. Transactions of the American Philosophical Society. New Series, Vol. 52, Part 3. July, 1962.

Russo, S., Sillmann, J., Sterl, A. Humid heat waves at different warming levels. Scientific Reports, 2017, 7: 7477.

Seibel, B. A., Walsh, P. J. Biological impacts of deepsea carbon dioxide injection inferred from indices of physiological performance. Journal of Experimental Biology, 2003, 206(Pt 4): 641-650.

Snæbjörnsdóttir, S. Ó., Sigfússon, B., Marieni, C., et al. Carbon dioxide storage through mineral carbonation. Nature Reviews Earth \& Environment, 2020, 1: 90-102.

Soeder, D. J. Unconventional: The Development of Natural Gas from the Marcellus Shale. Boulder, CO, USA, Geological Society of America Books, 2017.

Soeder, D. J. Fracking and the Environment. Cham, Switzerland, Springer Nature Switzerland AG, 2021.

Soeder, D. J., Borglum, S. J. The Fossil Fuel Revolution: Shale Gas and Tight Oil. Amsterdam, Netherlands, Elsevier,
2019.

Songolzadeh, M., Soleimani, M., Takht Ravanchi, M., et al. Carbon Dioxide separation from flue gases: A technological review emphasizing reduction in greenhouse gas emissions. The Scientific World Journal, 2014, 2014: 828131.

Tippett, M. K., Lepore, C., Cohen, J. E. More tornadoes in the most extreme U. S. tornado outbreaks. Science, 2016, 354(6318): 1419-1423.

USDOE. The United States Carbon Utilization and Storage Atlas, Fourth Edition. Washington, D. C., USA, DOE Office of Fossil Energy, 2012.

USDOE. What is an Enhanced Geothermal System (EGS)? Washington, D. C., USA, Geothermal Technologies Office, 2016.

USEIA. Country Analysis Executive Summary: China. Washington, D. C., USA, U. S. Energy Information Agency, 2020.

Watson, T., Bachu, S. Evaluation of the potential for gas and $\mathrm{CO}_{2}$ leakage along wellbores. SPE Drilling \& Completion, 2009, 24(1): 115-126.

Wrigley, E. A. Reconsidering the industrial revolution: England and Wales. Journal of Interdisciplinary History, 2018, 49(1): 9-42.

Xu, C., Kohler, T. A., Lenton, T. M., et al. Future of the human climate niche. Proceedings of the National Academy of Sciences of the United States of America, 2020, 117(21): 11350-11355. 